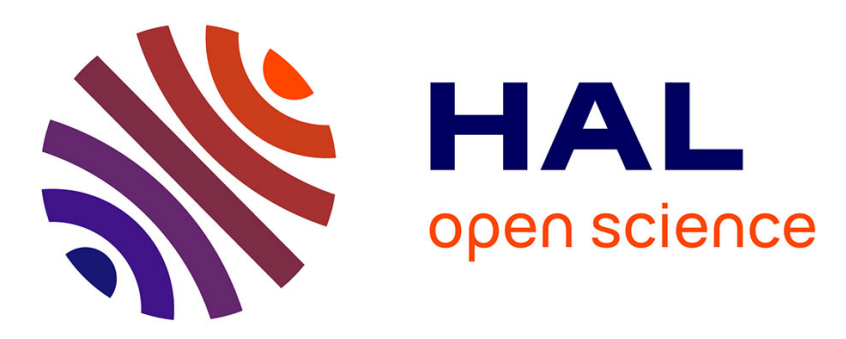

\title{
Divergent selection for residual feed intake affects the transcriptomic and proteomic profiles of pig skeletal muscle
}

Annie Vincent, Isabelle Louveau, Florence Gondret, Christine Trefeu, Hélène Gilbert, Louis Lefaucheur

\section{To cite this version:}

Annie Vincent, Isabelle Louveau, Florence Gondret, Christine Trefeu, Hélène Gilbert, et al.. Divergent selection for residual feed intake affects the transcriptomic and proteomic profiles of pig skeletal muscle. Journal of Animal Science, 2015, 93 (6), pp.2745-2758. 10.2527/jas2015-8928 . hal-01211015

\section{HAL Id: hal-01211015 https://hal.science/hal-01211015}

Submitted on 28 May 2020

HAL is a multi-disciplinary open access archive for the deposit and dissemination of scientific research documents, whether they are published or not. The documents may come from teaching and research institutions in France or abroad, or from public or private research centers.
L'archive ouverte pluridisciplinaire HAL, est destinée au dépôt et à la diffusion de documents scientifiques de niveau recherche, publiés ou non, émanant des établissements d'enseignement et de recherche français ou étrangers, des laboratoires publics ou privés. 


\title{
Divergent selection for residual feed intake affects the transcriptomic and proteomic profiles of pig skeletal muscle ${ }^{1,2}$
}

\author{
A. Vincent, $* \dagger$ I. Louveau, $* \dagger$ F. Gondret, $* \dagger$ C. Tréfeu, $* \dagger$ H. Gilbert, $\$ \$ \#$ and L. Lefaucheur* $* 3$ \\ *INRA, UMR1348 Pegase, F-35590 Saint-Gilles, France; †Agrocampus Ouest, UMR1348 Pegase, F-35000 Rennes, \\ France; \$INRA, UMR1388 GenPhySE, F-31326 Castanet-Tolosan, France; §Université de Toulouse, INP, ENSAT, \\ UMR1388 GenPhySE, F-31326 Castanet-Tolosan, France; \#Université de Toulouse, INP, ENVT, UMR1388 \\ GenPhySE, F-31076 Toulouse, France
}

\begin{abstract}
Improving feed efficiency is a relevant strategy to reduce feed cost and environmental waste in livestock production. Selection experiments on residual feed intake (RFI), a measure of feed efficiency, previously indicated that low RFI was associated with lower feed intake, similar growth rate, and greater lean meat content compared with high RFI. To gain insights into the molecular mechanisms underlying these differences, 24 Large White females from 2 lines divergently selected for RFI were examined. Pigs from a low-RFI ("efficient") and high-RFI ("inefficient") line were individually fed ad libitum from $67 \mathrm{~d}$ of age $(27 \mathrm{~kg} \mathrm{BW})$ to slaughter at $115 \mathrm{~kg}$ BW ( $n=8$ per group). Additional pigs of the highRFI line were feed restricted to the daily feed intake of the ad libitum low-RFI pigs $(n=8)$ to investigate the impact of selection independently of feed intake. Global gene and protein expression profiles were assessed in the LM collected at slaughter. The analyses involved a porcine commercial microarray and 2-dimensional gel electrophoresis. About 1,000 probes were differentially expressed $(P<0.01)$ between RFI lines. Only $10 \%$ of those probes were also affected by feed restriction. Gene functional classification indicated a greater expression of genes
\end{abstract}

involved in protein synthesis and a lower expression of genes associated with mitochondrial energy metabolism in the low-RFI pigs compared with the high-RFI pigs. At the protein level, 11 unique identified proteins exhibited a differential abundance $(P$ $<0.05$ ) between RFI lines. Differentially expressed proteins were generally not significantly affected by feed restriction. Mitochondrial oxidative proteins such as aconitase hydratase, ATP synthase subunit $\alpha$, and creatine kinase S-type had a lower abundance in the low-RFI pigs, whereas fructose-biphosphate aldolase A and glyceraldehyde-3-phosphate dehydrogenase, 2 proteins involved in glycolysis, had a greater abundance in those pigs compared with highRFI pigs. Antioxidant proteins such as superoxide dismutase and glutathione peroxidase 3 at the mRNA level and peroxiredoxin- 6 at the protein level were also less expressed in LM of the most efficient pigs, likely related to lower oxidative molecule production. Collectively, both the transcriptomic and proteomic approaches revealed a lower oxidative metabolism in muscle of the low-RFI pigs and all these modifications were largely independent of differences in feed intake.

Key words: feed efficiency, muscle, pig, proteome, transcriptome

(C) 2015 American Society of Animal Science. All rights reserved. J. Anim. Sci. 2015.93:2745-2758 doi: $10.2527 /$ jas $2015-8928$

\footnotetext{
${ }^{1}$ The authors would like to thank M. Alix, R. Janvier, J. Liger, V. Piedvache, P. Roger, and J. F. Rouault for their involvement in animal care and slaughtering and P. Ecolan and S. Tacher for their help in tissue sampling and expert technical assistance. We are also grateful to Y. Billon and A. Priet for providing divergently selected piglets. F. Moreews from the Sigenae team is acknowledged for updating the Agilent microarray annotation and thanks are also
}

due to the Proteomics Core Facility at Biogenouest (Rennes, France) for protein spot identification.

${ }^{2}$ The study was financially supported by the French National Research Agency (Agence Nationale de la Recherche, ANR-08GENM038, PIG_FEED project).

${ }^{3}$ Corresponding author: Louis.Lefaucheur@rennes.inra.fr

Received January 16, 2015.

Accepted April 6, 2015. 


\section{INTRODUCTION}

Improving feed efficiency is a major objective in livestock production to reduce feed cost and environmental waste. Feed efficiency can be assessed by estimating residual feed intake (RFI) of growing animals, defined as the feed consumed above or below what is predicted for growth and maintenance. Therefore, animals with low RFI (RFI') consume less feed than predicted and are qualified as efficient animals. In pigs, selection experiments have shown that reduced RFI is genetically correlated with lower feed intake and a leaner carcass, without any marked effects on growth rate (Gilbert et al., 2007). In skeletal muscle, larger fast-twitch glycolytic fibers with higher glycogen content and a greater proportion of glycolytic fibers have been reported in $\mathrm{RFI}^{-}$pigs compared with high RFI $\left(\mathbf{R F I}^{+}\right.$) pigs (Lefaucheur et al., 2011). In addition, lower activities of some glycolytic and oxidative enzymes have been reported in muscle of $\mathrm{RFI}^{-}$pigs (Le Naou et al., 2012; Faure et al., 2013), suggesting differences in muscle metabolic orientations for the storage and use of nutrients between lines. In cattle, differences in tissue metabolism have also been shown to contribute to differences in feed efficiency (Richardson and Herd, 2004). Nevertheless, the underlying biological basis of these differences remains to be fully established.

During the last decade, high-throughput technologies such as transcriptomics and proteomics have been used for large-scale genome expression analysis. These technologies may allow the identification of genes, proteins, or biological pathways that were not described so far to be responsive to the divergent selection for RFI. Therefore, this study aimed to investigate global modifications in gene and protein expressions in skeletal muscle between 2 pig lines divergently selected for RFI. Direct effects of RFI divergence on metabolic orientation was discriminated from the selection-induced differences in feed intake by considering an additional pair-fed $\mathrm{RFI}^{+}$group.

\section{MATERIALS AND METHODS}

\section{Animals}

The care and use of pigs were performed in compliance with the European Union legislation (directive 86/609/CEE; http://ec.europa.eu/food/fs/aw/ aw_legislation/scientific/86-609-eec_fr.pdf; accessed 27 January 2009) and the French legislation (Décret number 2001-464 29/05/01; http://ethique.ipbs.fr/sdv/ charteexpeanimale.pdf [accessed 29 January 2009]; agreement for animal housing number C-35-27532). Moreover, the technical and scientific staff involved in the experiment got an individual agreement from the French Veterinary Services to experiment on living animals. As previously described (Gilbert et al., 2007), ADFI and ADG from 35 to $95 \mathrm{~kg}$ were recorded on male candidates to selection, together with live backfat thickness at $95 \mathrm{~kg} \mathrm{BW}$. An RFI selection index was computed as a linear combination of those traits to account for growth requirements, with variations of maintenance requirements being ignored between fixed BW. In the present study, pigs from the seventh and eighth generations of divergent selection were considered. Average breeding values for RFI in those pigs were 57.6 and $-70.7 \mathrm{~g} / \mathrm{d}$ for the high-RFI $\mathrm{RFI}^{+}$and $\mathrm{RFI}^{-}$line, respectively, which were not different from the average breeding values calculated in these generations for sibs bred.

Purebred French Large White female pigs in the course of a divergent selection experiment for RFI were produced at the INRA research farms (GenESI at Surgères, Rouillé and Le Magneraud, France). This study was part of a larger contemporary work whose results related to performance, body composition, tissue energy metabolism, and hormonal status have already been published (Le Naou et al., 2012). Briefly, female piglets from the $\mathrm{RFI}^{-}(n=8)$ and $\mathrm{RFI}^{+}(n=$ 16) lines considered in the present study were weaned at $28 \mathrm{~d}$ of age and immediately transferred to the experimental facilities of INRA Pegase (Saint-Gilles, France). They were housed in collective pens ( 1 pen per line) at arrival and had free access to feed. At $67 \pm$ $1 \mathrm{~d}$ of age, pigs were individually housed up to commercial slaughter BW of $115 \mathrm{~kg}$. Pigs had free access to a transition diet the first week and were then divided into 3 experimental groups. In the first group, the $\mathrm{RFI}^{-}$ pigs were fed ad libitum ( $\left.\mathrm{RFI}^{-} ; n=8\right)$. Littermates of the $\mathrm{RFI}^{+}$line were divided into 2 experimental groups having either free access to feed $\left(\mathrm{RFI}^{+} ; n=8\right)$ or receiving the same amount of feed per metabolic $\mathrm{BW}\left(\mathrm{BW}^{0.60}\right)$ as $\mathrm{RFI}^{-}$pigs (feed-restricted $\mathrm{RFI}^{+}$pigs $\left.\left[\mathbf{R F I}^{+\mathbf{R}}\right] ; n=8\right)$. Pigs were weighed weekly and feed consumption was recorded daily. Daily feed allocated to $\mathrm{RFI}^{+\mathrm{R}}$ pigs was calculated weekly, based on the average daily feed consumption recorded during the week before in $\mathrm{RFI}^{-}$group, the average $\mathrm{BW}$ of $\mathrm{RFI}^{-}$ and $\mathrm{RFI}^{+\mathrm{R}}$ pigs at the day of calculation, and the predicted $\mathrm{ADG}$ of $\mathrm{RFI}^{-}$pigs for the week after.

Animals had free access to water and were fed with standard diets formulated for postweaning and growing periods as previously described (Le Naou et al., 2012). Pigs were weighed weekly and on slaughter day. Feed consumption (feed offered minus refusals) was recorded daily throughout the experiment. 


\section{Animal Slaughtering and Sample Collection}

Pigs were slaughtered at $115.2 \pm 1.5 \mathrm{~kg} \mathrm{BW}$ by electronarcosis followed by exsanguination $2 \mathrm{~h}$ after their first morning meal, at the experimental slaughterhouse of INRA (Saint-Gilles, France). Samples of LM were collected at the last rib level within $20 \mathrm{~min}$ after death, cut into small pieces, snap frozen in liquid nitrogen, and stored at $-75^{\circ} \mathrm{C}$ until further analyses.

\section{Ribonucleic Acid Extraction}

For total RNA extraction, 80 to $100 \mathrm{mg}$ of frozen muscle was homogenized in Trizol reagent (Invitrogen, Cergy-Pontoise, France) using a TissueLyser (Qiagen, Hilden, Germany) and was then treated as previously described (Vincent et al., 2012). The RNA was purified using a silica-membrane technology under vacuum (Nucleospin 8 RNA kit; Macherey Nagel, Hoerdt, France). The quantification of RNA was performed by using a NanoDrop ND-1000 spectrophotometer (Thermo Scientific, Illkirch, France). Ratios of A260:A280 and A260:A230 were greater than 1.8 in all samples, denoting good purity. The integrity of total RNA was assessed using the Agilent RNA 6000 Nano kit with an Agilent 2100 Bioanalyzer (Agilent Technologies France, Massy, France). Average RNA integrity numbers were $8.1 \pm 0.5($ mean $\pm \mathrm{SD})$.

\section{Microarray Analysis}

Transcriptomics analyses were performed using the porcine commercial Agilent-026440 Oligo Microarray (V2, 4x44K, GPL15007; Agilent Technologies France), containing 43,803 probes. To update annotation of the porcine gene chip probe sets, Agilent 60 -mer probes were further analyzed on the basis of probe and contig sequence homology searches using pig transcripts (National Center for Biotechnology Information [NCBI] Sus scrofa RefSeq; http://www.ncbi.nlm.nih. gov/RefSeq/ [accessed 5 March 2012]; UniProt; http:// www.uniprot.org/ [accessed 8 March 2012]) or transcripts from related species (Homo sapiens, Bos taurus, and Mus musculus). Annotation was based on similarity and quality criteria as follows: at least 18 consecutive base pairs within the 60 -mer probe sequence and $85 \%$ homology (Casel et al., 2009). In total, 33,231 probes ( $76 \%$ of total) were annotated, corresponding to 12,332 unique gene symbols.

Each sample was labeled with Cy3 dye using the Low RNA Input Linear Amplification Kit (Agilent Technologies France) following the manufacturer's instructions. Briefly, a 2-step procedure was used to generate fluorescent complementary RNA by using T7 RNA polymerase. Samples were then purified with an
RNeasy MinElute kit (Qiagen). Microarray hybridizations were performed in Agilent's SureHyb hybridization chambers containing $1.65 \mu \mathrm{g}$ of Cy3-labeled complementary RNA sample per hybridization. Hybridization reactions were performed at $65^{\circ} \mathrm{C}$ for 17 h using Agilent's Gene Expression Hybridization kit. After washing, microarrays were scanned at $5 \mu \mathrm{m} /$ pixel resolution using the Agilent DNA Microarray Scanner G2505C, and images were analyzed with Agilent Feature Extraction Software (version 10.7.3.1; protocol GE1_107_Sep09). All analyses were then performed using the $\mathrm{R}$ software version 2.10.0 (R Development Core Team, 2008). Raw spot intensities were first submitted to quality filtration based on 4 criteria: intensity, uniformity, saturation, and outliers detection. Among the 43,803 probes evaluated per microarray, 29,364 probes $(67 \%)$ were kept after quality filtration. Intensities of filtered spots were $\log 2$ transformed, and data were normalized by median centering, that is, subtracting the median value across all probes from all raw values within each sample. Microarray selected data have been deposited into the Gene Expression Omnibus repository and are publicly available through Gene Expression Omnibus accession number GSE47769 (http://www.ncbi.nlm.nih. gov/geo/query/acc.cgi?acc=GSE47769; accessed 10 June 2013). Data were then submitted to ANOVA using the fixed effects of the genetic line $\left(\mathrm{RFI}^{-}\right.$or $\left.\mathrm{RFI}^{+}\right)$ or feed restriction $\left(\mathrm{RFI}^{+\mathrm{R}}\right.$ or $\left.\mathrm{RFI}^{+}\right)$. Differentially expressed (DE) probes with $P$-values lower than 0.01 were then selected for further functional analysis.

\section{Functional Analysis}

Probes that were DE between $\mathrm{RFI}^{-}$and $\mathrm{RFI}^{+}$pigs were then divided into down- or upregulated probes. These 2 lists of probes were further investigated by an enrichment analysis of specific Gene Ontology (GO) terms for Biological Processes and Kyoto Encyclopedia Genes and Genomes pathways using the Database for Annotation, Visualization and Integrated Discovery (DAVID) bioinformatic resources (http://david.abcc. ncifcrf.gov/home.jsp; accessed 10 April 2012; Huang. et al., 2008; Dennis et al., 2003). In DAVID analysis, the GO terms FAT were selected to filter the broadest terms without overshadowing the more specific ones. The lists of probes were uploaded using official gene symbol obtained with DAVID Gene Acession Conversion Tool. The $P$-values for enrichment were computed by a modified Fisher's exact test, using the porcine microarray as the background. The REVIGO Web server (http://revigo.irb.hr/; accessed 4 February 2013) was also used to reduce redundancy and to find the most representative GO terms (Supek et al., 2011). 
The SimRel was used as the semantic similarity measure within the human GO database (Schlicker et al., 2006). Tables were chosen to visualize the results.

\section{Proteome Analysis}

Total proteins were extracted from $50 \mathrm{mg}$ of powdered frozen muscle tissue homogenized into $1 \mathrm{~mL}$ lysis buffer containing 7.5 $M$ urea, $2 M$ thiourea, $2 \%$ 3-((3-cholamidopropyl)dimethylammonium)-1-propanesulfonate, $40 \mathrm{~m} M$ Tris base, $50 \mathrm{~m} M$ dithiothreitol (DTT), $1 \mathrm{~m} M$ EDTA, 1\% immobilized $\mathrm{pH}$ gradient (IPG) buffer $\mathrm{pH} 3$ to 11 nonlinear (NL; GE Healthcare, Uppsala, Sweden), $1 \mu \mathrm{g} / \mathrm{mL}$ pepstatin, and $1.5 \mathrm{mg} /$ $\mathrm{mL}$ complete protease inhibitor cocktail (Roche, Mannheim, Germany), using a handheld Teflonpestle-glass Potter-Elvehjem homogenizer. The lysate was incubated at room temperature for $1 \mathrm{~h}$ with rotational shaking followed by centrifugation at $60,000 \times$ $g$ for $1 \mathrm{~h}$ at $18^{\circ} \mathrm{C}$. Supernatant was collected avoiding the fat layer, aliquoted, and stored at $-75^{\circ} \mathrm{C}$ until further analysis. Protein concentration in the supernatants was determined using the Quick Start Bradford kit (Bio-Rad, Marnes-la-Coquette, France) with BSA as the standard. For the first dimension electrophoresis, $300 \mu \mathrm{g}$ protein was diluted in a rehydration buffer containing $0.5 \%$ IPG buffer $\mathrm{pH} 3$ to $11 \mathrm{NL}$ and Destreack solution (GE Healthcare) to a final volume of $450 \mu \mathrm{L}$. Precast NL immobilized gradient strips ( $\mathrm{pH}$ 3-11, $24 \mathrm{~cm}$; GE Healthcare) were rehydrated overnight $(16 \mathrm{~h})$ at room temperature in a passive way with the solubilized proteins under $3.5 \mathrm{~mL}$ of cover fluid (GE Healthcare). The IPG strips were then subjected to isoelectric focusing on an Ettan IPGphorII system (GE Healthcare) at $20^{\circ} \mathrm{C}$ with a step gradient protocol ranging from 150 to $8,000 \mathrm{~V}$ for $21 \mathrm{~h}(150 \mathrm{~V}$ for $1 \mathrm{~h}$, $300 \mathrm{~V}$ for $3 \mathrm{~h}, 300$ to $600 \mathrm{~V}$ for $1 \mathrm{~h}, 600$ to $1,000 \mathrm{~V}$ for $4 \mathrm{~h} 30 \mathrm{~min}, 1,000$ to $8,000 \mathrm{~V}$ for $3 \mathrm{~h}$, and $8,000 \mathrm{~V}$ for $8 \mathrm{~h} 45 \mathrm{~min}$ ) to reach a total of $88,600 \mathrm{~V} \cdot \mathrm{h}$. At the completion of focusing, the strips were equilibrated by soaking for $15 \mathrm{~min}$ in $50 \mathrm{mM}$ Tris- $\mathrm{HCl}$ buffer $\mathrm{pH}$ 8.8, $6 \mathrm{M}$ urea, 30\% glycerol, $2 \%$ SDS, and $65 \mathrm{mM}$ DTT followed by an additional 15 min equilibration in the same buffer replacing DTT by $4.5 \%$ iodoacetamide and adding $0.03 \%$ bromophenol blue sodium salt R-250 (Sigma -Aldrich, Saint-Quentin Fallavier, France). Equilibrated IPG strips were transferred onto the top of a $12.5 \%$ uniform SDS-PAGE and sealed with $0.5 \%(\mathrm{wt} / \mathrm{vol})$ low-melting-point agarose. The SDS-PAGE was performed in a vertical Ettan DALTsix system (GE Healthcare) using upper $2 \mathrm{x}$ and lower 1x buffer (number 161-0772; Bio-Rad) at $15^{\circ} \mathrm{C}$. Gels were run at $5 \mathrm{~W} /$ gel for $45 \mathrm{~min}$ followed by 17 $\mathrm{W} /$ gel until bromophenol blue front reached the bot- tom of the gel. After migration, gels were fixed overnight in $40 \%$ methanol $/ 10 \%$ acetic acid, rinsed 3 times for $5 \mathrm{~min}$ in water, and stained by $0.12 \%$ Coomasie Brilliant Blue G-250 (Bio-Rad) in 10\% phosphoric acid, $10 \%$ ammonium sulfate, and $20 \%$ methanol for $24 \mathrm{~h}$. Following destaining in water, gels were scanned using an UMAX ImageScanner (GE Healthcare) at 300 dots per inch and spot detection and quantification were performed by image analysis (Melanie 2D gel analysis software version 7.0; SIB Swiss Institute of Bioinformatics, Lausanne, Switzerland). To take into account experimental variation (protein loading and staining), 2-dimensional (2D) gels were normalized within each gel by dividing each spot volume by the total volume of all valid spots on the gel (spot relative volume expressed as vol/vol $\times 10^{6}$ ). Highly abundant protein spots such as actin were manually deleted because of inaccurate quantification due to saturation. Data were then analyzed by ANOVA using the GLM procedure of SAS (SAS Inst. Inc., Cary, NC) with the fixed effect of the experimental group $\left(\mathrm{RFI}^{-}, \mathrm{RFI}^{+}\right.$, and $\mathrm{RFI}^{+\mathrm{R}}$ ). A $P$-value lower than 0.05 was retained for statistical significance.

Preparative gels with $600 \mu \mathrm{g}$ of proteins from pooled samples were performed for spot picking. The protein spots that were different between $\mathrm{RFI}^{-}$and $\mathrm{RFI}^{+}$pigs were punched out of preparative gels using a OneTouch 2D gel manual spotpicker (Gel Company, San Francisco, CA). In gel tryptic digestion and protein identification by mass spectrometry were performed in the high-core proteomic facilities of Biogenouest (Rennes, France) as previously described (Colinet et al., 2012). Briefly, tryptic peptides were analyzed by nano-liquid chromatography-tandem mass spectrometry (LC-MS/MS) using nano-liquid chromatography system Ultimate 3000 (DIONEX; LC Packings, Amsterdam, The Netherlands) coupled online to a linear ion trap HCT Ultra P Discovery system mass spectrometer (BrukerDaltoniK GmBh, Bremen, Germany). The proteinScape 2.1 software (BrukerDaltoniK GmBh) was used to submit tandem mass spectrometry data to the following database: SwissProt sequence database restricted to mammalia taxonomy (http://www.uniprot.org; accessed 9 October 2012) and NCBI nonredundant sequences databases of mammalian proteins (http://www.ncbi.nlm. nih.gov; accessed 9 October 2012) using the Mascot search engine (Mascot server version 2.2; http:// www.matrixscience.com; accessed 9 October 2012). Parameters were set as follows: trypsin as enzyme with one allowed miscleavage, carbamidomethylation of cysteins as fixed modification, and methionine oxidation as variable modifications. The mass tolerance for parent and fragment ions was set to 1.2 and $0.5 \mathrm{Da}$, 
respectively. Results were scored using the probability-based Mowse algorithm, where the protein score is $-10 \times \log (P)$ and $P$ is the probability that the observed match is a random event. In our conditions, a score greater than 80 indicated a significant identification $(P$ $<0.05$ ) and at least 4 matched peptides per protein and $20 \%$ sequence coverage were also required to avoid incorrect identification. The accuracy of the experimental to theoretical isoelectric point and molecular weight were also considered. Identified proteins were then classified according to their biological process terms provided in GO Consortium for Homo sapiens by using correspondence to gene name and their functions proposed on the SwissProt/TrEMBL protein databases (http://www.uniprot.org/; accessed 25 October 2012).

\section{Quantitative Real-Time PCR}

Expressions of selected genes found to be DE between RFI lines by transcriptome and proteome analyses or by transcriptome analysis only were further evaluated by quantitative real-time PCR (qPCR). Complementary DNA was synthesized from $1 \mu \mathrm{g}$ of total RNA previously used in microarray analysis, using a High Capacity cDNA Reverse Transcription Kit (Applied Biosystems, Foster City, CA). Primers (Table 1) were designed from porcine sequences using Primer Express software 3.0 (Applied Biosystems). For each primer pair, the amplification efficiency of qPCR reaction was determined using calibration curves generated with 6 decreasing concentrations of cDNA from pooled muscle samples (obtained from 12.5 to $12.5 \times 10^{-3} \mathrm{ng}$ RNA). Amplification reaction was performed in duplicate in $12.5 \mu \mathrm{L}$ with $2.5 \mathrm{ng}$ of reverse-transcribed RNA and both forward and reverse primers (200 $\mathrm{n} M$ each) in 1x PCR buffer (Fast SYBR Green Master Mix; Applied Biosystems). A StepOnePlus Real Time PCR system (Applied Biosystems) was used. Thermal cycling conditions were as follows: $50^{\circ} \mathrm{C}$ for $2 \mathrm{~min}$ and $95^{\circ} \mathrm{C}$ for $20 \mathrm{~s}$ followed by 40 cycles of denaturation at $95^{\circ} \mathrm{C}$ for $3 \mathrm{~s}$ and annealing at $60^{\circ} \mathrm{C}$ for $30 \mathrm{~s}$. Specificity of the amplification products was checked by dissociation curves analysis. Three genes were found invariant and, therefore, used as reference for normalization according to the geNorm algorithm (Vandesompele et al., 2002): hypoxanthine phosphoribosyltransferase 1 (HPRT1), peptidylpropyl isomerase A (cyclophilin A) (PPIA), and tyrosine 3-monooxygenase/tryptophan 5-monooxygenase activation protein, zeta polypeptide (YWHAZ). For each sample, a normalization factor (NF) was calculated using the geNorm algorithm and used for subsequent normalization. For each gene, the normalized expression level $N$ was calculated accord- ing to the following formula (Pfaffl, 2001): $N=E^{-\Delta \mathrm{Cq}}$ (sample - calibrator)/NF, in which $E$ is calculated from the slope of calibration curve, $\mathrm{Cq}$ is the quantification cycle, and calibrator is a pool of all muscle samples. Data were analyzed by ANOVA with the fixed effect of genetic line by using the R software version 2.10.0 (R Development Core Team, 2008). A $P$-value $<0.05$ was retained for statistical significance.

\section{RESULTS}

\section{Residual Feed Intake and Feed Restriction Effects on Performance}

The $\mathrm{RFI}^{-}$and $\mathrm{RFI}^{+\mathrm{R}}$ pigs were older $(+10$ to $13 \mathrm{~d}$; $P<0.001)$ than $\mathrm{RFI}^{+}$pigs at the same slaughter $\mathrm{BW}$ (Table 2). From $67 \mathrm{~d}$ of age to slaughter, ADG did not differ between $\mathrm{RFI}^{-}$and $\mathrm{RFI}^{+}$pigs and was lower in $\mathrm{RFI}^{+\mathrm{R}}$ pigs $(-10 \%)$. Daily feed intake was similar in $\mathrm{RFI}^{-}$and $\mathrm{RFI}^{+\mathrm{R}}$ pigs $(P>0.05)$, whereas ADFI was markedly lower $(P<0.001)$ in these groups compared with $\mathrm{RFI}^{+}$pigs when adjusted to metabolic BW (182, 181 , and $209 \mathrm{~g} \cdot \mathrm{d}^{-1} \cdot \mathrm{kg}^{-1} \mathrm{BW}^{0.60}$ in $\mathrm{RFI}^{-}, \mathrm{RFI}^{+\mathrm{R}}$, and $\mathrm{RFI}^{+}$pigs, respectively) or calculated on an as-fed basis $(2.23,2.32$ and $2.65 \mathrm{~kg} / \mathrm{d}$, respectively). The G:F was greater $(P<0.001)$ in $\mathrm{RFI}^{-}$than $\mathrm{RFI}^{+}$pigs. Feed restriction in $\mathrm{RFI}^{+\mathrm{R}}$ was rather moderate $(-13 \%$ on a metabolic $\mathrm{BW}$ basis), so that $\mathrm{RFI}^{+\mathrm{R}}$ pigs exhibited the same G:F as $\mathrm{RFI}^{+}$pigs (0.35). Carcass lean meat content tended to be greater $(P=0.08)$ in $\mathrm{RFI}^{-}$and $\mathrm{RFI}^{+\mathrm{R}}$ pigs than in $\mathrm{RFI}^{+}$pigs.

\section{Residual Feed Intake and Feed Restriction Effects on Muscle Transcriptome}

In muscle, 1,013 probes were DE between $\mathrm{RFI}^{-}$ and $\mathrm{RFI}^{+}$pigs $(P<0.01)$ with $82 \%$ of them exhibiting a fold change below the absolute value of 1.5 (Table 3). Among these probes, 674 (corresponding to 338 annotated genes) were overexpressed and 339 (corresponding to 188 annotated genes) were underexpressed in $\mathrm{RFI}^{-}$pigs compared with $\mathrm{RFI}^{+}$pigs. The number of DE probes $(P<0.01)$ between $\mathrm{RFI}^{+}$and $\mathrm{RFI}^{+\mathrm{R}}$ pigs was lower (727) than the number of DE probes between $\mathrm{RFI}^{-}$and $\mathrm{RFI}^{+}$pigs. Among them, 402 probes were overexpressed in $\mathrm{RFI}^{+\mathrm{R}}$ pigs compared with $\mathrm{RFI}^{+}$pigs. Only 53 of these probes were also found to be overexpressed in $\mathrm{RFI}^{-}$vs. $\mathrm{RFI}^{+}$pigs. Among the 325 probes downregulated in $\mathrm{RFI}^{+\mathrm{R}}$ pigs compared with $\mathrm{RFI}^{+}$pigs, only 37 were also downregulated in $\mathrm{RFI}^{-}$vs. $\mathrm{RFI}^{+}$pigs. Therefore, only $10 \%$ of the DE probes between RFI lines were also affected by feed restriction. Therefore, the functional analysis 
Table 1. Primer sequences used for analysis of gene expression by quantitative real-time PCR

\begin{tabular}{|c|c|c|c|}
\hline $\begin{array}{l}\text { Gene } \\
\text { symbol }\end{array}$ & Description & Accession number ${ }^{1}$ & Primer sequence $\left(5^{\prime}-3^{\prime}\right)^{2}$ \\
\hline$\overline{A Q P 4}$ & Aquaporin 4 & ENSSSCT00000004120 & $\begin{array}{l}\text { F: CAGAAAAGCCCCTACCTGTTGA } \\
\text { R: CGTGACAGCGGGATTGATG }\end{array}$ \\
\hline$C D 40$ & $\begin{array}{c}\text { CD40 molecule, tumor necrosis factor receptor } \\
\text { superfamily member } 5\end{array}$ & ENSSSCT00000008144 & $\begin{array}{l}\text { F: GCCCGCCAGGACAGAAA } \\
\text { R: GGAACTGCAAGGAAGGCATTC }\end{array}$ \\
\hline CSRNP3 & Cysteine-serine-rich nuclear protein 3 & ENSSSCT00000017319 & $\begin{array}{l}\text { F: TCAATCCATCCACTTCCAATCA } \\
\text { R: GCCGCTTCTCCCTTTTGAG }\end{array}$ \\
\hline GAPDH & Glyceraldehyde-3-phosphate dehydrogenase & AF017079.1 & $\begin{array}{c}\text { F: CATCCATGACAACTTCGGCA } \\
\text { R: GCATGGACTGTGGTCATGAGTC }\end{array}$ \\
\hline$G P X 3$ & Glutathione peroxidase 3 & ENSSSCT00000018610 & $\begin{array}{c}\text { F: GCTTCCCCTGCAACCAATT } \\
\text { R: GGACATACCTGAGAGTGGACAGAA }\end{array}$ \\
\hline$O A Z 3$ & Ornithine decarboxylase antizyme 3 & NM_001122996 & $\begin{array}{c}\text { F: ATTGTATTCGGCTGGGAACCT } \\
\text { R: GGCGGAAGTGGAAGTCTAGCT }\end{array}$ \\
\hline PCIF1 & Phosphorylated CTD-interacting factor 1 & XM_003360023 & $\begin{array}{c}\text { F: CAGCGTGGAGATGCACATG } \\
\text { R: GAGCCACAGCTTGCTGAAGTAG }\end{array}$ \\
\hline PRMT3 & Protein arginine methyltransferase 3 & XM_003360703 & $\begin{array}{l}\text { F: CAGGTGAAGGCTTGAAAGGAA } \\
\text { R: TCACAATGAGAGAACGTGGATCTT }\end{array}$ \\
\hline SOD2 & Superoxide dismutase 2 , mitochondrial & NM_214127.2 & $\begin{array}{l}\text { F: GCGCTGAAAAAGGGTGATGT } \\
\text { R: ACCGTTAGGGCTCAGATTTGTC }\end{array}$ \\
\hline WDHD1 & WD repeat and HMGbox DNA binding protein 1 & ENSSSCT00000005569 & $\begin{array}{l}\text { F: GCCATTCCAGTCAGGTTCTACAC } \\
\text { R: TCCAATAGAATTCCACACCATGAA }\end{array}$ \\
\hline$H P R T 1^{3}$ & Hypoxanthine phospho-ribosyltransferase 1 & DQ845175 & $\begin{array}{l}\text { F: TACCTAATCATTATGCCGAGGATTT } \\
\text { R: AGCCGTTCAGTCCTGTCCAT }\end{array}$ \\
\hline$P P I A^{3}$ & Peptidylpropyl isomerase A & NM_214353 & $\begin{array}{l}\text { F: AGCACTGGGGAGAAAGGATT } \\
\text { R: AAAACTGGGAACCGTTTGTG }\end{array}$ \\
\hline$Y W H A Z^{3}$ & $\begin{array}{c}\text { Tyrosine 3-mono-oxygenase/tryptophan } \\
\text { 5-monooxugenase activation protein, zeta } \\
\text { polypeptide }\end{array}$ & XM_001927228 & $\begin{array}{l}\text { F: ATGCAACCAACACATCCTATC } \\
\text { R: GCATTATTAGCGTGCTGTCTT }\end{array}$ \\
\hline
\end{tabular}

\footnotetext{
${ }^{1}$ Accession number in the National Center for Biotechnology Information database (http://www.ncbi.nlm.nih.gov/gene; accessed 14 May 2013) or Ensembl project database (http://www.ensembl.org/Sus_scrofa/Info/Index; accessed 14 May 2013) for pig sequences.

${ }^{2} \mathrm{~F}=$ forward primer; $\mathrm{R}=$ reverse primer.

${ }^{3}$ Genes used as reference for quantitative real-time PCR normalization.
}

was further focused on the effects of genetic differences between RFI lines.

Functional analysis of DE genes between $\mathrm{RFI}^{-}$ and $\mathrm{RFI}^{+}$groups showed an overrepresentation of pathways related to oxido-reduction process and energy oxidative metabolism in $\mathrm{RFI}^{+}$pigs (Table 4). Especially, the expression levels of genes encoding glutathione peroxidase 3 (GPX3) and superoxide dismutase 2 (SOD2), 2 enzymes involved in the detoxification of reactive oxygen species (ROS), were lower in $\mathrm{RFI}^{-}$than in $\mathrm{RFI}^{+}$pigs. Moreover, many genes involved in the respiratory electron transport chain, the generation of precursor metabolites and energy, and the tricarboxylic acid cycle were downregulated in $\mathrm{RFI}^{-}$pigs compared with $\mathrm{RFI}^{+}$pigs (Table 4). This concerned the expression of genes encoding mitochondrial NADH dehydrogenase 1 (ND1), 2 (ND2), and 4 (ND4); NADH dehydrogenase (ubiquinone) $1 \beta$ subcomplex 9 (NDUFB9); isocitrate dehydrogenase $3(\mathrm{NAD}+) \alpha(I D H 3 A)$; and cytochrome C $(C Y C S$; Table 4). Electron-transfer-flavoprotein beta polypeptide (ETFB), which serves as a specific electron acceptor for several acyl-CoA dehydrogenases and transfers the electrons to the mitochondrial respira- tory chain via electron-transferring-flavoprotein dehydrogenase, was also underexpressed in $\mathrm{RFI}^{-}$pigs. However, other functionally important genes might have been missed because they did not fit into a cluster. Therefore, additional individual DE genes were also taken into account to extend the global functional analysis (Table 5). Dihydrolipoamide dehydrogenase $(D L D)$ and pyruvate dehydrogenase kinase isozyme 1 (PDK1), 2 genes involved in mitochondrial pyruvate metabolism, were found to be underexpressed in $\mathrm{RFI}^{-}$pigs. Acyl-CoA thioesterase 8 (ACOT8) and lipase A (LIPA), coding for proteins involved in acylCoA hydrolysis and lipase activity, respectively, were also underexpressed in $\mathrm{RFI}^{-}$pigs compared with $\mathrm{RFI}^{+}$ pigs. Vascular endothelial growth factor A (VEGFA), a gene coding for a growth factor active in angiogenesis and vasculogenesis, was also notably underexpressed in $\mathrm{RFI}^{-}$pigs. The expressions of 2 other genes related to apotosis, CSRNP3 (i.e., a transcriptional factor involved in apoptosis) and $O A Z 3$, an inhibitor of ornithine decarboxylase, which is an enzyme involved in the antioxidative defense and resistance to apoptosis through the generation of polyamines, were also expressed at lower levels in $\mathrm{RFI}^{-}$pigs (Table 5). Finally, 
Table 2. Growth performance and carcass traits in pigs divergently selected for low $\left(\mathrm{RFI}^{-}\right)$or high $\left(\mathrm{RFI}^{+}\right)$ residual feed intake (RFI) having either free $\left(\mathrm{RFI}^{-}\right.$and $\mathrm{RFI}^{+}$) or restricted $\left(\mathrm{RFI}^{+\mathrm{R}}\right)$ access to feed from $67 \mathrm{~d}$ of age to slaughter. Values are least squares means

\begin{tabular}{|c|c|c|c|c|c|}
\hline Item & $\begin{array}{c}\mathrm{RFI}^{-} \\
(n=8)\end{array}$ & $\begin{array}{l}\mathrm{RFI}^{+} \\
(n=8)\end{array}$ & $\begin{array}{l}\mathrm{RFI}^{+\mathrm{R}} \\
(n=8)\end{array}$ & $\mathrm{RSD}^{1}$ & $P$-value \\
\hline \multicolumn{6}{|l|}{ Growth traits } \\
\hline 67-d-old BW, kg & $25.7^{\mathrm{b}}$ & $31.1^{\mathrm{a}}$ & $30.5^{\mathrm{a}}$ & 3.9 & 0.02 \\
\hline Final BW, kg & 115.8 & 114.9 & 115.2 & 1.6 & 0.51 \\
\hline Final age, d & $168^{\mathrm{a}}$ & $158^{\mathrm{b}}$ & $172^{\mathrm{a}}$ & 6.23 & $<0.001$ \\
\hline $\mathrm{ADG}, \mathrm{g} / \mathrm{d}$ & $892^{\mathrm{a}}$ & $927^{\mathrm{a}}$ & $819^{\mathrm{b}}$ & 39 & $<0.001$ \\
\hline \multicolumn{6}{|l|}{ Feed intake } \\
\hline $\begin{array}{r}\text { Daily feed intake, } \\
\mathrm{g} \cdot \mathrm{d}^{-1} \cdot \mathrm{kg} \mathrm{BW}^{0.60}\end{array}$ & $182^{\mathrm{a}}$ & $209^{\mathrm{b}}$ & $181^{\mathrm{a}}$ & 10 & $<0.001$ \\
\hline $\mathrm{G}: \mathrm{F}$ & $0.40^{\mathrm{a}}$ & $0.35^{\mathrm{b}}$ & $0.35^{\mathrm{b}}$ & 0.02 & $<0.001$ \\
\hline \multicolumn{6}{|l|}{ Carcass traits } \\
\hline $\begin{array}{l}\text { Lean meat } \\
\text { content, \% }\end{array}$ & 59.0 & 57.2 & 58.9 & 2.0 & 0.08 \\
\hline
\end{tabular}

${ }^{\mathrm{a}, \mathrm{b}}$ Within a row, means without a common superscript differ $(P<0.10)$.

${ }^{1} \mathrm{RSD}=$ residual $\mathrm{SD}$ (corresponding to the root-mean-square error of the full ANOVA model).

genes associated with antigen processing and presentation of peptide antigen and endosome transport, such as $H L A-A, H L A-B$, and $H L A-C$, were downregulated in $\mathrm{RFI}^{-}$pigs (Table 4). Functional analysis of upregulated genes in $\mathrm{RFI}^{+\mathrm{R}}$ pigs compared with $\mathrm{RFI}^{+}$pigs reveals significant enrichments of GO terms associated with RNA processing, intracellular protein transport, and ubiquitin-dependent protein catabolic processes.

Conversely, translation biological processes such as translation itself, ribonucleoprotein complexes, and mRNA processing were upregulated pathways in $\mathrm{RFI}^{-}$ vs. $\mathrm{RFI}^{+}$pigs (Table 4). In particular, genes coding for translation initiation and elongation factors (EEF1A1, $E E F 1 G, E I F 2 B 5, E I F 2 S 2$, and EIF6) and RNA processing (WDHD1, POP4, CPSF1, and CPSF3) were overexpressed in $\mathrm{RFI}^{-}$vs. $\mathrm{RFI}^{+}$pigs (Table 5). $C A P N 2$, coding for the millimolar-calpain, a calciumsensitive cysteine protease, was also overexpressed in $\mathrm{RFI}^{-}$pigs. Finally, expression level of the glyceraldehyde-3-phosphate dehydrogenase (GAPDH), a metabolic enzyme involved in the glycolytic pathway, was greater in $\mathrm{RFI}^{-}$pigs than in $\mathrm{RFI}^{+}$pigs (Table 5).

\section{Residual Feed Intake and Feed Restriction Effects on Muscle Proteome}

About 807 spots were detected and matched between the 24 gels (Fig. 1). Among them, 20 spots were found with a differential abundance between $\mathrm{RFI}^{-}$and $\mathrm{RFI}^{+}$pigs $(P<0.05)$ and 15 spots were less intense in $\mathrm{RFI}^{-}$pigs compared with $\mathrm{RFI}^{+}$pigs. Fourteen spots, corresponding to 11 unique proteins, were successful-
Table 3. Number of probes differentially expressed $(P<0.01)$ in muscle of pigs divergently selected for low $\left(\mathrm{RFI}^{-}\right)$or high $\left(\mathrm{RFI}^{+}\right)$residual feed intake (RFI) having either free $\left(\mathrm{RFI}^{-}\right.$and $\mathrm{RFI}^{+}$) or restricted $\left(\mathrm{RFI}^{+\mathrm{R}}\right)$ access to feed from $67 \mathrm{~d}$ of age to slaughter at $115 \mathrm{~kg} \mathrm{BW}$

\begin{tabular}{|c|c|c|c|c|}
\hline \multirow[b]{2}{*}{$\begin{array}{l}\text { Fold-change } \\
\text { groups }\end{array}$} & \multicolumn{2}{|c|}{$\mathrm{RFI}^{-} / \mathrm{RFI}^{+}$pigs } & \multicolumn{2}{|c|}{$\mathrm{RFI}^{+\mathrm{R}} / \mathrm{RFI}^{+}$pigs } \\
\hline & $\begin{array}{c}\text { Over- } \\
\text { expressed }\end{array}$ & $\begin{array}{l}\text { Under- } \\
\text { expressed }\end{array}$ & $\begin{array}{c}\text { Over- } \\
\text { expressed }\end{array}$ & $\begin{array}{l}\text { Under- } \\
\text { expressed }\end{array}$ \\
\hline Total & 674 & 339 & 402 & 325 \\
\hline $\mathrm{FC}^{1} \geq 1.5$ & 72 & 110 & 18 & 80 \\
\hline $\mathrm{FC} \geq 2$ & 27 & 32 & 1 & 3 \\
\hline
\end{tabular}

${ }^{1} \mathrm{FC}=$ fold change.

ly identified (Table 6). Three proteins, each resolved as double spots exhibiting similar molecular weights but different isoelectric points (Fig. 1), corresponded to ATP synthase subunit $\alpha$ (ATP5A1), creatine kinase S-type (CKMT2), and heat shock protein $\beta-1$ (HSPB1). Differences between $\mathrm{RFI}^{-}$and $\mathrm{RFI}^{+}$pigs were similar between double spots for ATP5A1, and CKMT2 and opposite for HSPB1. The 11 identified proteins could be divided into 4 different functional groups: metabolism related (6 proteins), stress related ( 2 proteins), transport related (2 proteins), and structure related (1 protein; Table 6$)$. Among the metabolism-related proteins, 3 were related to mitochondrial oxidative metabolism (ACO2, ATP5A1, and CKMT2) and were less abundant in $\mathrm{RFI}^{-}$than $\mathrm{RFI}^{+}$animals $(P<0.05)$. The stress-related protein peroxiredoxin-6 (PRDX6), involved in protection against oxidative stress, was decreased $(P<0.05)$ in $\mathrm{RFI}^{-}$animals compared with $\mathrm{RFI}^{+}$animals and was downregulated by feed restriction, so that $\mathrm{RFI}^{+\mathrm{R}}$ pigs and $\mathrm{RFI}^{-}$pigs did not differ. The cytoplasmic glycerol-3-phosphate dehydrogenase (GPD1), an enzyme involved in the glycerol phosphate shuttle, was also less abundant in $\mathrm{RFI}^{-}$than $\mathrm{RFI}^{+}$animals. Conversely, 2 proteins related with glycolytic metabolism (GAPDH and fructose-bisphosphate aldolase A [ALDOA]) had a greater abundance in $\mathrm{RFI}^{-}$than $\mathrm{RFI}^{+}$pigs. These metabolism-related proteins were not influenced by feed restriction in the $\mathrm{RFI}^{+}$pigs. Among transport related proteins, serotransferrin (TF), a secreted protein involved in iron transport, and myoglobin (MB) involved in oxygen transport within myofibers were less abundant in $\mathrm{RFI}^{-}$pigs compared with $\mathrm{RFI}^{+}$pigs $(P<0.05)$. Relative abundance of myoglobin was not significantly influenced by feed restriction, whereas abundance of TF protein was lower in $\mathrm{RFI}^{+\mathrm{R}} \mathrm{VS}$. $\mathrm{RFI}^{+}$ pigs $(P<0.05)$. Finally, vascular smooth muscle actin (ACTA2), a structure-related protein, was identified as having a lower abundance in $\mathrm{RFI}^{-}$than $\mathrm{RFI}^{+}$animals 
Table 4. Most significant overrepresented Gene Ontology (GO) biological processes identified from the differentially expressed genes between muscles of low $\left(\mathrm{RFI}^{-}\right)$and high $\left(\mathrm{RFI}^{+}\right)$residual feed intake pigs having free access to feed from $67 \mathrm{~d}$ of age to slaughter

\begin{tabular}{|c|c|c|c|c|}
\hline GO accession & Description & No. ${ }^{1}$ & $\begin{array}{c}\log 10 \\
P \text {-value }\end{array}$ & Gene symbol \\
\hline \multicolumn{5}{|c|}{ Downregulated in $\mathrm{RFI}^{-}$vs. $\mathrm{RFI}^{+}$} \\
\hline GO:0055114 & Oxidation-reduction process & 19 & -4.243 & $\begin{array}{c}M E 1, N D 1, N D 4, L O C 396756, N D U F B 9, N D 2, C Y C S, M O S C 2, \\
I D H 3 A, S O D 2, R D H 11, S L C 1 A 3, H S D L 2, F M O 1, G P X 3, D L D, \\
H S D 17 B 4, L O C 733694, \text { and ETFB }\end{array}$ \\
\hline GO:0048002 & $\begin{array}{l}\text { Antigen processing and presentation } \\
\text { of peptide antigen }\end{array}$ & 5 & -3.958 & $S L A-3, H L A-A, H L A-C, H L A-B$, and $B 2 M$ \\
\hline GO:0022900 & Electron transport chain & 8 & -3.696 & ND1, SLC1A3, ND4, LOC396756, NDUFB9, ND2, CYCS, and ETFB \\
\hline GO:0006091 & $\begin{array}{l}\text { Generation of precursor metabolites } \\
\text { and energy }\end{array}$ & 10 & -2.248 & $\begin{array}{c}\text { ND1, SLC1A3, ND4, LOC396756, PGAM4, NDUFB9, } \\
\text { ND2, CYCS, ETFB, and IDH3A }\end{array}$ \\
\hline GO:0016197 & Endosome transport & 4 & -1.614 & STX16, PIKFYVE, VPS13A, and HOOK3 \\
\hline GO:0045944 & $\begin{array}{l}\text { Positive regulation of transcription } \\
\text { from RNA polymerase II promoter }\end{array}$ & 8 & -1.327 & TAF2, CSRNP3, MITF, SIX1, CAND1, TCEA1, TCF7L2, and STAT3 \\
\hline \multicolumn{5}{|c|}{ Upregulated in $\mathrm{RFI}^{-}$vs. $\mathrm{RFI}^{+}$} \\
\hline GO:0006412 & Translation & 37 & -23.118 & $\begin{array}{l}\text { EIF6, RPL18, RPL14, RPLP0, RPLP1, FAU, RPL10, RPL12, } \\
\text { RPL36AL, EIF2B5, LOC645139, RPS18, RPS19, RPS12, UBA52, } \\
\text { RPS26, RPL7, RPL6, RPL8, RPS20, RPS23, RPSA, EEF1A1, PAIP1, } \\
\text { RPL23A, DENR, RPS6, COPS5, LOC100049695, RPS19P3, RPS3, } \\
\text { EEF1G, RPS15A, RPL29, RPL23, RPL21, and EIF2S2 }\end{array}$ \\
\hline GO:0022613 & $\begin{array}{l}\text { Ribonucleoprotein complex } \\
\text { biogenesis }\end{array}$ & 12 & -3.690 & $\begin{array}{c}\text { EIF6, GTPBP4, SNUPN, LOC100049695, GNL3L, RPS6, } \\
\text { SFRS5, RPS19, RPL7, RPLP0, POP4, and TGS1 }\end{array}$ \\
\hline GO:0042692 & Muscle cell differentiation & 9 & -2.918 & $\begin{array}{c}\text { SYNE1, ACTA1, MAPK12, ERBB2, GLMN, SOX6, } \\
\text { NEURL2, CAPN2, and CACNA1S }\end{array}$ \\
\hline GO:0006379 & Messenger RNA cleavage & 3 & -1.463 & $P O P 4, C P S F 3$, and $C P S F 1$ \\
\hline GO:0030099 & Myeloid cell differentiation & 5 & -1.4411 & RPS19, PSEN1, EPB42, SOX6, and VPS33A \\
\hline GO:0006469 & $\begin{array}{l}\text { Negative regulation of protein kinase } \\
\text { activity }\end{array}$ & 4 & -1.346 & PSEN1, HEXIM2, SNX6IGF2, and PKIA \\
\hline
\end{tabular}

${ }^{1}$ Number of genes involved in the GO term.

$(P<0.05)$ and was downregulated by feed restriction $\left(\mathrm{RFI}^{+\mathrm{R}}\right.$ pigs $<\mathrm{RFI}^{+}$pigs; $\left.P<0.05\right)$.

\section{Data Validation by Quantitative Real-Time PCR}

Among the DE proteins, only changes in GAPDH were similarly observed both at the mRNA and protein levels between lines. Other DE proteins (ACO2, ATP5A1, CKMT2, ALDOA, GPD1, MB, TF, PRDX6, and HSPB1) were not DE at the mRNA level.

We checked 10 genes showing high fold change in expression levels between $\mathrm{RFI}^{-}$and $\mathrm{RFI}^{+}$pigs and involved in various functional categories: oxidative stress (GPX3, SOD2, and $O A Z 3)$, glycolysis $(G A P D H)$, immune response (CD40), apoptose (CSRNP3 and OAZ3), translation (PCIF1 and $W D H D 1)$, protein methylation (PRMT3), and water transport (AQP4). The differential expressions between $\mathrm{RFI}^{-}$and $\mathrm{RFI}^{+}$pigs were confirmed by qPCR (Fig. 2) for all tested genes.

\section{DISCUSSION}

The current study enriches our knowledge on the molecular mechanisms underlying variations in RFI in pigs selected from a larger group of pigs (Le Naou et al., 2012) by focusing on skeletal muscle transcriptomic and proteomic profiles. To discriminate selection effects from those induced by differences in feed intake, some pigs from the $\mathrm{RFI}^{+}$line were pair fed at the feeding level of pigs from the $\mathrm{RFI}^{-}$line during the growing-finishing period. Although Lkhagvadorj et al. (2010) found important effects of an acute caloric restriction on the adipose tissue and liver transcriptomes of pigs divergently selected for RFI, the present study revealed only minor changes in muscle adaptive responses to feed restriction. This discrepancy between our study and the abovementioned one can be related to the organ, variations in experiment duration (several weeks vs. $8 \mathrm{~d}$, respectively), and/or level of feed restriction (13 vs. $75 \%$, respectively). Because only $10 \%$ of the DE probes between $\mathrm{RFI}^{-}$and $\mathrm{RFI}^{+}$groups were also affected by feed restriction within the $\mathrm{RFI}^{+}$ pigs, our data show that effects of divergent selection for RFI on molecular features of skeletal muscle were quite independent of differences in pig voluntary feed intake between lines. 
Table 5. Fold change between the most relevant genes in different biological pathways found between muscles of low $\left(\mathrm{RFI}^{-}\right)$and high $\left(\mathrm{RFI}^{+}\right)$residual feed intake pigs

\begin{tabular}{|c|c|c|c|}
\hline $\begin{array}{l}\text { Gene } \\
\text { symbol }\end{array}$ & $\begin{array}{c}P \text {-value } \\
\text { maximum }^{1}\end{array}$ & $\begin{array}{l}\mathrm{RFI}^{-/} \\
\mathrm{RFI}^{+2}\end{array}$ & $\begin{array}{l}\text { Main Gene Ontology }(\mathrm{GO}) \\
\text { biological process terms }\end{array}$ \\
\hline$\overline{N D 1}$ & 0.0045 & -1.4 & \multirow{6}{*}{$\begin{array}{l}\text { GO:0022904 respiratory electron } \\
\text { transport chain }\end{array}$} \\
\hline ND2 & 0.0089 & -1.3 & \\
\hline ND4 & 0.0094 & -1.2 & \\
\hline NDUFB 9 & 0.0055 & -1.8 & \\
\hline CYCS & 0.0074 & -1.3 & \\
\hline ETFB & 0.0009 & -1.3 & \\
\hline \multirow[t]{2}{*}{$I D H 3 A$} & \multirow[t]{2}{*}{0.0082} & \multirow[t]{2}{*}{-1.2} & $\begin{array}{c}\text { GO:0005975 carbohydrate metabolic } \\
\text { process }\end{array}$ \\
\hline & & & GO:0006099 tricarboxylic acid cycle \\
\hline$G A P D H$ & 0.0036 & 1.4 & GO:0006006 glucose metabolic process \\
\hline$D L D$ & 0.0090 & -1.2 & \multirow{2}{*}{$\begin{array}{c}\text { GO:0006090 pyruvate metabolic } \\
\text { process }\end{array}$} \\
\hline$P D K 1$ & 0.0027 & -1.4 & \\
\hline \multirow[t]{2}{*}{ ACOT8 } & \multirow[t]{2}{*}{0.0005} & \multirow[t]{2}{*}{-1.2} & $\begin{array}{c}\text { GO:0006637 acyl-CoA metabolic } \\
\text { process }\end{array}$ \\
\hline & & & GO:0016559 peroxisome fission \\
\hline$L I P A$ & 0.0069 & -1.5 & GO:0006629 lipid metabolic process \\
\hline$V E G F A$ & 0.0080 & -1.5 & GO:0001570 vasculogenesis \\
\hline$G P X 3$ & 0.0010 & -1.5 & \multirow{2}{*}{$\begin{array}{c}\text { GO:0006979 response to oxidative } \\
\text { stress }\end{array}$} \\
\hline SOD2 & 0.0073 & -1.3 & \\
\hline CSRNP3 & 0.0001 & -2.8 & GO:0006915 apoptotic process \\
\hline \multirow[t]{2}{*}{$O A Z 3$} & \multirow[t]{2}{*}{$1.4 \times 10^{-6}$} & \multirow[t]{2}{*}{-1.6} & $\begin{array}{l}\text { GO:0006521 regulation of cellular } \\
\text { amino acid metabolic process }\end{array}$ \\
\hline & & & $\begin{array}{l}\text { GO:0034641 cellular nitrogen } \\
\text { compound metabolic process }\end{array}$ \\
\hline EIF2B5 & 0.0073 & 1.2 & \multirow{2}{*}{ GO:0006413 translational initiation } \\
\hline EIF2S2 & 0.0041 & 1.2 & \\
\hline EEF1A1 & 0.0098 & 1.3 & \multirow{2}{*}{ GO:0006414 translational elongation } \\
\hline$E E F 1 G$ & 0.0066 & 1.1 & \\
\hline EIF6 & 0.0087 & 1.2 & \multirow{5}{*}{$\begin{array}{c}\text { GO:0042256 mature ribosome assembly } \\
\text { GO:0006396 RNA processing }\end{array}$} \\
\hline WDHD1 & 0.010 & 1.3 & \\
\hline POP4 & 0.001 & 1.6 & \\
\hline CPSF1 & 0.0057 & 1.1 & \\
\hline CPSF3 & 0.0076 & 1.3 & \\
\hline \multirow[t]{2}{*}{ CAPN2 } & 0.0024 & 1.3 & GO:0006508 proteolysis \\
\hline & & & GO:0016540 protein autoprocessing \\
\hline
\end{tabular}

\footnotetext{
${ }^{1}$ The highest $P$-value is reported when several probes are differentially expressed for a unique gene.

${ }^{2}$ The smallest value of expression ratio is reported when several probes are differentially expressed for a gene. Ratios are inversed and preceded by a minus sign for values lower than 1 .
}

\section{Lower Muscle Oxidative Metabolism in Low-RFI Pigs}

The number of DE mRNA between $\mathrm{RFI}^{-}$and $\mathrm{RFI}^{+}$ pigs was much greater than the number of differential proteins. These observations likely result from methodological concerns. Indeed, when the microarray technology allows analyses of all spotted genes, an overwhelming number of proteins cannot be detected on 2D gels because their abundance is below the detection threshold. However, common pathways in

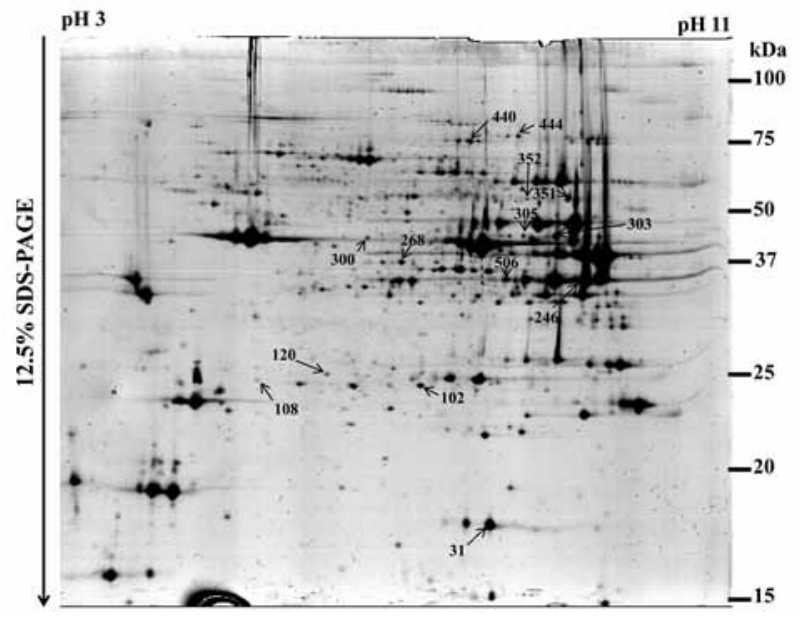

Figure 1. Representative 2-dimensional electrophoresis image of LM separated using an immobilized $\mathrm{pH}$ gradient (IPG) 3 to 11 nonlinear strip (GE Healthcare, Uppsala, Sweden) in the first dimension and 12.5\% SDSPAGE in the second dimension. The protein loading was $300 \mu \mathrm{g}$ and the gel was stained with colloidal Coomassie Brilliant Blue G-250. Numbered spots (14 spots) were identified by nano-liquid chromatography-tandem mass spectrometry (LC-MS/MS) and listed in Table 6.

which individual genes were involved could be found across methodologies. Thus, both transcriptomic and proteomic data indicate that energy metabolism of the predominantly white glycolytic LM was turned to a less oxidative pattern in $\mathrm{RFI}^{-}$pigs compared with $\mathrm{RFI}^{+}$pigs. This assumption is supported by the finding of an underexpression in the $\mathrm{RFI}^{-}$pigs of dihydrolipoamide dehydrogenase $(D L D)$, a gene that encodes a protein component of the pyruvate dehydrogenase complex regulating the flux of 2-carbon acetyl units from pyruvate through acetyl-CoA into the Krebs cycle and is one of the major enzymes regulating homeostasis of carbohydrate fuels in mammals. This enzyme activity is regulated by a reversible phosphorylation/ dephosphorylation cycle by a specific pyruvate dehydrogenase kinase, and the gene encoding the isoform 1 of this protein was also underexpressed in $\mathrm{RFI}^{-}$pigs. Furthermore, the $I D H 3 A$ gene catalyzing the allosterically regulated rate-limiting step of the tricarboxylic acid cycle was also downregulated in the $\mathrm{RFI}^{-}$pigs. These findings are further supported by proteomic data showing a lower abundance of aconitase hydratase (ACO2) and ATP synthase subunit $\alpha$ (ATP5A1) in $\mathrm{RFI}^{-}$pigs. Using a similar gel-based proteome analysis in pig LM, Hwang et al. (2005) identified the same corresponding spots as ACO2 and ATP5A1, which validates the accuracy of spot identification in the present study. The ACO2 catalyzes the isomerization of citrate to isocitrate via cis-aconitate in the tricarboxylic acid cycle, whereas ATP5A1 is a subunit of the inner mitochondrial membrane ATP synthase complex $\left(\mathrm{F}_{0} \mathrm{~F}_{1}\right.$ ATP synthase or Complex V), which produces ATP from ADP in the presence of a proton 
Table 6. Differentially expressed muscle proteins in pigs divergently selected for low $\left(\mathrm{RFI}^{-}\right)$or high $\left(\mathrm{RFI}^{+}\right)$ residual feed intake (RFI) having either free $\left(\mathrm{RFI}^{-}\right.$and $\left.\mathrm{RFI}^{+}\right)$or restricted $\left(\mathrm{RFI}^{+\mathrm{R}}\right)$ access to feed from $67 \mathrm{~d}$ of age to slaughter

\begin{tabular}{|c|c|c|c|c|c|c|c|c|c|c|c|}
\hline \multirow{2}{*}{$\begin{array}{l}\text { Spot } \\
\text { no. }^{1}\end{array}$} & \multirow{2}{*}{$\begin{array}{l}\text { Gene } \\
\text { symbol }\end{array}$} & \multirow[b]{2}{*}{ Protein name ${ }^{2}$} & \multirow{2}{*}{$\begin{array}{l}\text { Theoretical } \\
\mathrm{pI} / \mathrm{Mr}^{3}\end{array}$} & \multirow[b]{2}{*}{ Score $^{4}$} & \multirow[b]{2}{*}{$\mathrm{MP} / \mathrm{Sc}^{5}$} & \multirow{2}{*}{$\begin{array}{l}\mathrm{RFI}^{-}: \\
\mathrm{RFI}^{+6}\end{array}$} & \multicolumn{3}{|c|}{$\begin{array}{l}\text { Spot relative volume } \\
\text { vol } / \text { vol } \times 10^{6}\end{array}$} & \multirow[b]{2}{*}{$\mathrm{RSD}^{8}$} & \multirow[b]{2}{*}{$P$-value ${ }^{8}$} \\
\hline & & & & & & & $\mathrm{RFI}^{-}$ & $\mathrm{RFI}^{+}$ & $\mathrm{RFI}^{+\mathrm{R}}$ & & \\
\hline$\overline{444}$ & $\mathrm{ACO} 2$ & $\begin{array}{l}\text { Aconitase hydratase, } \\
\text { mitochondrial }\end{array}$ & $9.0 / 85.7$ & 1,295 & $25 / 25$ & $\begin{array}{ll}-1.8 \\
\end{array}$ & $203^{\mathrm{a}}$ & $369^{\mathrm{b}}$ & $343^{b}$ & 107 & 0.01 \\
\hline 351 & ATP5A1 & $\begin{array}{l}\text { ATP synthase subunit } \alpha \text {, } \\
\text { mitochondrial }\end{array}$ & $9.7 / 59.7$ & 1,298 & $29 / 35$ & -1.6 & $683^{\mathrm{a}}$ & $1,060^{\mathrm{b}}$ & $844^{\mathrm{ab}}$ & 240 & 0.02 \\
\hline 352 & ATP5A1 & $\begin{array}{l}\text { ATP synthase subunit } \alpha, \\
\text { mitochondrial }\end{array}$ & $9.7 / 59.7$ & 932 & $15 / 27$ & -1.6 & $140^{\mathrm{a}}$ & $219^{\mathrm{b}}$ & $170^{\mathrm{ab}}$ & 56 & 0.03 \\
\hline 303 & $C K M T 2$ & $\begin{array}{c}\text { Creatine kinase S-type, } \\
\text { mitochondrial }\end{array}$ & $9.3 / 47.2$ & 1,301 & $29 / 42$ & -1.5 & $995^{\mathrm{a}}$ & $1,527^{\mathrm{b}}$ & $1,322^{\mathrm{ab}}$ & 365 & 0.03 \\
\hline 305 & $C K M T 2$ & $\begin{array}{l}\text { Creatine kinase S-type, } \\
\text { mitochondrial }\end{array}$ & $9.3 / 47.2$ & 937 & $12 / 35$ & -1.4 & $240^{\mathrm{a}}$ & $341^{\mathrm{b}}$ & $246^{\mathrm{a}}$ & 78 & 0.03 \\
\hline 506 & $G A P D H$ & $\begin{array}{c}\text { Glyceraldehyde-3-phosphate } \\
\text { dehydrogenase }\end{array}$ & $9.3 / 35.8$ & 732 & $15 / 30$ & 1.3 & $1,563^{\mathrm{a}}$ & $1,184^{b}$ & $1,410^{\mathrm{ab}}$ & 346 & 0.04 \\
\hline 246 & $A L D O A$ & $\begin{array}{c}\text { Fructose-bisphosphate } \\
\text { aldolase A }\end{array}$ & $9.2 / 39.3$ & 1,289 & $32 / 42$ & 1.3 & $26,459^{\mathrm{a}}$ & $21,055^{\mathrm{b}}$ & $22,877^{\mathrm{ab}}$ & 3,722 & 0.03 \\
\hline 268 & $G P D 1$ & $\begin{array}{l}\text { Glycerol-3-phosphate } \\
\text { dehydrogenase }[\mathrm{NAD}(+)] \\
\text { cytoplasmic }\end{array}$ & $6.9 / 37.6$ & 488 & $8 / 20$ & -1.7 & $369^{\mathrm{a}}$ & $637^{\mathrm{b}}$ & $483^{\mathrm{ab}}$ & 194 & 0.04 \\
\hline 120 & PRDX6 & Peroxiredoxin-6 & $5.7 / 25.0$ & 390 & $7 / 44$ & -1.2 & $221^{\mathrm{a}}$ & $262^{\mathrm{b}}$ & $218^{\mathrm{a}}$ & 33 & 0.03 \\
\hline 102 & HSPB 1 & Heat shock protein $\beta-1$ & $6.3 / 22.9$ & 529 & $12 / 31$ & -1.7 & $360^{\mathrm{a}}$ & $601^{\mathrm{b}}$ & $447^{\mathrm{ab}}$ & 173 & 0.03 \\
\hline 108 & $H S P B 1$ & Heat shock protein $\beta-1$ & $6.3 / 22.9$ & 290 & $5 / 28$ & 1.6 & $159^{\mathrm{a}}$ & $99^{\mathrm{b}}$ & $101^{\mathrm{b}}$ & 38 & 0.01 \\
\hline 440 & $T F$ & Serotransferrin & $7.1 / 76.9$ & 1,382 & $28 / 36$ & -1.4 & $444^{\mathrm{a}}$ & $618^{b}$ & $368^{\mathrm{a}}$ & 162 & 0.02 \\
\hline 31 & $M B$ & Myoglobin & $6.9 / 17.1$ & 682 & $32 / 64$ & -1.4 & $4,686^{\mathrm{a}}$ & $6,345^{\mathrm{b}}$ & $5,247^{\mathrm{ab}}$ & 1,242 & 0.04 \\
\hline 300 & ACTA2 & Actin, aortic smooth muscle & $5.1 / 42.0$ & 600 & $13 / 30$ & -1.4 & $174^{\mathrm{a}}$ & $251^{\mathrm{b}}$ & $178^{\mathrm{a}}$ & 48 & 0.01 \\
\hline \multicolumn{12}{|c|}{${ }^{\mathrm{a}, \mathrm{b}}$ Within a row, means without a common superscript differ $(P<0.05)$. } \\
\hline \multicolumn{12}{|c|}{$\begin{array}{l}{ }^{2} \text { Protein name and accession numbers were derived from the National Center for Biotechnology Information database (http://www.ncbi.nlm.nih.gov } \\
\text { ccessed } 9 \text { October 2012). }\end{array}$} \\
\hline \multicolumn{12}{|c|}{${ }^{3} \mathrm{pI}=$ isoelectric point $; \mathrm{Mr}=$ molecular weight. } \\
\hline \multicolumn{12}{|c|}{${ }^{4}$ Score from MASCOT (Mascot server version 2.2; http://www.matrixscience.com; accessed 9 October 2012). } \\
\hline \multicolumn{12}{|c|}{$\begin{array}{l}{ }^{5} \mathrm{MP}=\text { the number of matched peptides in the database search; } \mathrm{Sc}=\text { protein sequence coverage of the matched peptides in relation to the full-length } \\
\text { equence. }\end{array}$} \\
\hline
\end{tabular}

gradient generated across the inner mitochondrial membrane. Other genes encoding proteins implicated in the mitochondrial electron transport chain such as ND1, ND2, ND4, NDUFB9, CYCS, and ETFB were also found to be underexpressed in $\mathrm{RFI}^{-}$compared with $\mathrm{RFI}^{+}$animals using the transcriptomic analysis. Finally, proteomic data showed less creatine kinase S-type (CKMT2) in $\mathrm{RFI}^{-}$pigs. The CKMT2 is a mitochondrial creatine kinase responsible for the transfer of high-energy phosphate to creatine, which plays a central role in energy transport in tissues with large and fluctuating energy demands such as skeletal muscle (Qin et al., 1999). Importantly, this lower oxidative capacity of $\mathrm{RFI}^{-}$pigs compared with $\mathrm{RFI}^{+}$pigs postulated here based on transcriptomic and proteomic changes in response to RFI selection is supported by enzymatic data previously obtained in a larger group of pigs from the same generation (Le Naou et al., 2012); lower specific activities of citrate synthase, an indicator of mitochondrial oxidative capacity, and of hydroxy-acyl-CoA dehydrogenase, an indicator of fatty acid $\beta$-oxidation potential, have been demonstrated in $\mathrm{LM}$ of $\mathrm{RFI}^{-}$pigs compared with $\mathrm{RFI}^{+}$pigs (Le Naou et al., 2012). On the other hand, Grubbs et al. (2013b) found a greater abundance of the dihydrolipoyl dehydrogenase, aconitate hydratase, and ATP synthase in isolated mitochondria from the red portion of the semitendinosus muscle of $\mathrm{RFI}^{-}$pigs compared with $\mathrm{RFI}^{+}$pigs. Discrepancies between studies are likely due to the fact that Grubbs and colleagues studied intrinsic mitochondrial composition, whereas our results included both differences in mitochondria content as well as differences in their intrinsic composi- 


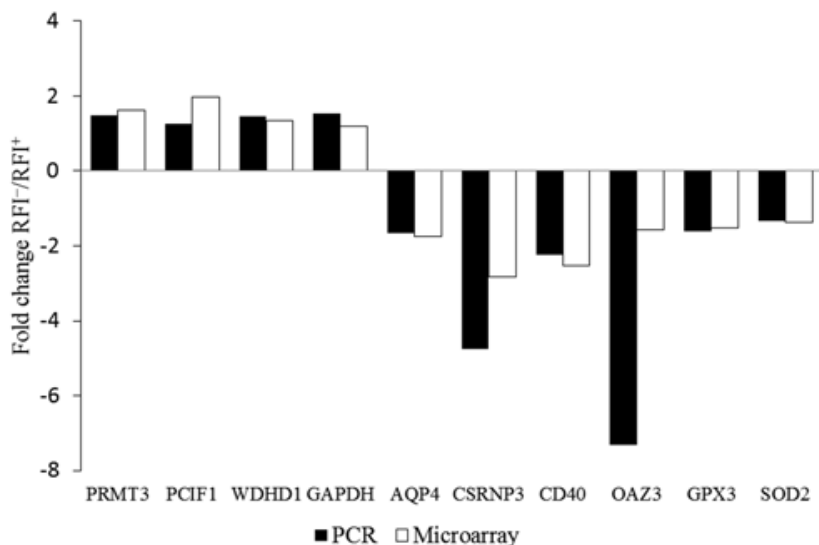

Figure 2. Comparison of microarray and quantitative real-time PCR (qPCR) data for gene expression ratio between low $\left(\mathrm{RFI}^{-}\right)$and high $\left(\mathrm{RFI}^{+}\right)$ residual feed intake pigs in LM. Ratios lower than 1 were expressed as negative numbers (i.e., a ratio of 0.5 is expressed as -2 ). All significant differences between $\mathrm{RFI}^{-}$and $\mathrm{RFI}^{+}$microarray data $(P<0.01)$ were confirmed by qPCR data $(P<0.05)$, except for superoxide dismutase 2 $(S O D 2 ; P=0.08) . A Q P 4=$ aquaporin $4 ; C D 40=C D 40$ molecule $T N F$ receptor superfamily member $5 ; C S R N P 3=$ cysteine-serine-rich nuclear protein 3; GAPDH = glyceraldehyde-3-phosphate dehydrogenase; GPX3 = glutathione peroxidase $3 ; O A Z 3=$ ornithine decarboxylase antizyme 3; PCIF1 = phosphorylated CTD-interacting factor $1 ;$ PRMT3 = protein arginine methyltransferase $3 ; W D H D 1=W D$ repeat and $H M G b o x D N A$ binding protein 1 .

tion. The responses of energy metabolism to selection for RFI might be also different between muscle types.

The current study also indicates that the genetic selection for RFI induces changes in the expression levels of various genes and proteins related to vascularization. The proteomic approach reported lower amount of TF, $\mathrm{MB}$, and ACTA2 in $\mathrm{RFI}^{-}$pigs than in $\mathrm{RFI}^{+}$pigs. TF is an iron binding transport protein that is responsible for the transport of iron in the plasma from sites of absorption to sites of storage and utilization, such as in the heme prosthetic group of hemoglobin, myoglobin and cytochromes. MB serves as a transporter of oxygen within muscle fibers and its decrease in $\mathrm{RFI}^{-}$pigs compared with $\mathrm{RFI}^{+}$pigs is then consistent with the reduced oxidative metabolism in the $\mathrm{LM}$ of $\mathrm{RFI}^{-}$pigs. Finally, ACTA2 is a vascular smooth muscle actin present in blood vessel walls and its lower abundance in $\mathrm{RFI}^{-}$pigs could be related with a reduced amount of blood vessels (Fatigati and Murphy, 1984), in accordance with the lower muscle oxidative metabolism in those pigs. The $V E G F A$ gene, a member of the PDGF/VEGF growth factor family encoding a protein that acts on endothelial cells and induces angiogenesis and vasculogenesis (Neufeld et al., 1999), was also underexpressed in RFI ${ }^{-}$ pigs compared with $\mathrm{RFI}^{+}$pigs by the transcriptomic approach. These differences in muscle oxidative capacity and vascularization may result from selection-induced differences in physical activity, as muscle oxidative metabolism is known to be stimulated by long term physical activity (Pette and Staron, 1997) and the importance of VEGF in regulating skeletal muscle capillarity has been emphasized in studies dealing with adaptation to exercise (Richardson et al., 2000) and stimulated skeletal muscle (Hang et al., 1995). In support, $\mathrm{RFI}^{-}$pigs have been shown to exhibit a lower physical activity resulting from a lower eating frequency, a shorter daily feeding time (De Haer et al., 1993; Meunier-Salaün et al., 2014), and a lower standing time (Meunier-Salaün et al., 2014).

Besides the downregulation of oxidative metabolism in $\mathrm{LM}$ of $\mathrm{RFI}^{-} \mathrm{vs}$. $\mathrm{RFI}^{+}$pigs, the current transcriptomic and proteomic data also suggest an upregulation of the glycolytic metabolism in $\mathrm{RFI}^{-}$pigs. Indeed, there was an increase in the expression of GAPDH, a glycolytic enzyme, both at the transcriptional and protein levels in those pigs and a greater abundance of ALDOA evidenced only at the protein level. This higher expression of glycolytic enzymes in muscle of $\mathrm{RFI}^{-}$pigs is in agreement with the higher percentage of fast-twitch glycolytic fibers previously reported in the same muscle after 4 generations of selection (Lefaucheur et al., 2011). However, previous studies reported a reduced activity of lactate dehydrogenase, an enzyme involved in the terminal route of glycolysis, in LM of pigs selected for $\mathrm{RFI}^{-}$suggesting reduced glycolysis in those pigs (Le Naou et al., 2012; Faure et al., 2013). Using a proteomic approach, Grubbs et al. (2013b) also found a lower abundance of LDHA in the mitochondrial fraction of $\mathrm{LM}$ from $\mathrm{RFI}^{-}$pigs but the fact that LDHA is a cytosolic protein prompts us to be careful in interpreting those results. Altogether, the effects of RFI selection on muscle glycolytic metabolism remain rather unclear and deserve further study.

\section{Data are Consistent with a Lower Oxidative Stress and Apoptosis in Low-RFI Pigs}

The current study highlights the downregulation of 3 molecules involved in cell defense against ROS in $\mathrm{RFI}^{-}$pigs compared with $\mathrm{RFI}^{+}$pigs. Peroxiredoxin-6 was decreased at the protein level, whereas SOD2 and GPX3 exhibited decreased mRNA levels. Because the metabolic challenge during physical exercise results in an elevated generation of ROS (Bo et al., 2013), the observed greater levels of antioxidant molecules in the muscle of $\mathrm{RFI}^{+}$pigs could be an adaptive mechanism to cope with a higher and deleterious ROS production (Radak et al., 2005). In accordance, a greater ROS production has been reported in mitochondria from semitendinosus muscle in $\mathrm{RFI}^{+}$pigs (Grubbs et al., 2013a) and from breast muscle in broilers with low feed efficiency (Bottje and Carstens, 2009). Furthermore, the mitochondria protein profile in LM indicated a greater abundance of proteins in- 
volved in oxidative and antioxidative stress in the less efficient $\mathrm{RFI}^{+}$line (Grubbs et al., 2013b). Therefore, available data suggest that muscle of $\mathrm{RFI}^{-}$pigs may have less mitochondria, which would be intrinsically more efficient and less prone to produce ROS than those of $\mathrm{RFI}^{+}$pigs. In the present experiment, GPD1 showed a higher abundance in $\mathrm{RFI}^{+}$than $\mathrm{RFI}^{-}$pigs at the protein level. This enzyme could counterbalance ROS production in $\mathrm{RFI}^{+}$pigs while maintaining a high oxidative metabolism. Indeed, GPD1 plays a critical role in carbohydrate and lipid metabolism by catalyzing the reversible conversion of dihydroxyacetone phosphate and NADH to glycerol-3-phosphate and NAD+ in the cytoplasm. Importantly, GPD1 is part of the glycerol phosphate shuttle that facilitates the transfer of reducing equivalents generated during glycolysis in the cytosol (NADH) to coenzyme Q in the mitochondrial electron transport chain, transferring cytoplasmic reducing equivalents through flavin adenine dinucleotide $\left(\mathbf{F A D H} \mathbf{2}_{2}\right.$ ) directly to complex II, thus bypassing complex I, a site where ROS are generated. The global reaction is exothermic, driven by the difference in free energy between NADH in the cytosol and reduced $\mathrm{FADH}_{2}$ in the mitochondria, which could contribute to the greater feed efficiency and lower heat loss of $\mathrm{RFI}^{-}$pigs than of $\mathrm{RFI}^{+}$pigs (Barea et al., 2010). The underexpression of $O A Z 3$, an inhibitor of ornithine decarboxylase, in $\mathrm{RFI}^{-} \mathrm{vs}$. $\mathrm{RFI}^{+}$pigs could also improve the antioxidative defense in $\mathrm{RFI}^{-}$ pigs because ornithine decarboxylation is the first step in the synthesis of polyamines that are important as antioxidants. Moreover, cysteine-serine-rich nuclear protein 3 (CSRNP3), a transcriptional factor involved in apoptosis, was also underexpressed at the mRNA level in $\mathrm{RFI}^{-}$pigs. Altogether, available data suggest a reduced ROS production in LM of the $\mathrm{RFI}^{-}$pigs, which might be also associated with lower oxidative stress and apoptosis compared with $\mathrm{RFI}^{+}$pigs.

\section{Transcriptomic Data Suggest a Greater Muscle Protein Synthesis in Low-RFI Pigs}

Transcriptomic data highlighted differences in the expression of some genes involved in protein synthesis or degradation. Notably, genes encoding initiation and elongation translation factor subunits (EEF1A1, EEF1G, EIF 2S2, EIF2B5, and EIFO), and type I protein arginine $N$-methyltransferase (PRMT3) involved in the maturation of the 80 and $56 \mathrm{~S}$ ribosomal proteins were overexpressed in $\mathrm{RFI}^{-}$vs. $\mathrm{RFI}^{+}$pigs. Feed restriction may also affect some genes in protein metabolism. Indeed, protein synthesis and protein catabolic pathways were simultaneously enriched in $\mathrm{RFI}^{+\mathrm{R}}$ pigs when compared with $\mathrm{RFI}^{+}$pigs. However, it remains elusive to relate these changes observed at the mRNA levels to differences in carcass lean meat content reported between the different groups. Indeed, we failed to identify any differences between lines or due to feed restriction for the relative abundance in these proteins using the proteomic approach. Similarly, it has been reported that markers of protein synthesis did not differ between 2 Yorkshire pig lines selected for divergent feed efficiency (Cruzen et al., 2013). Except for the gene encoding for the millimolar-calpain protease (CAPN2) involved in muscle protein degradation, which was overexpressed in $\mathrm{RFI}^{-}$animals compared with $\mathrm{RFI}^{+}$animals, expression levels of other genes linked to protein catabolism were not modified by selection in the current study. These latter observations are consistent with the lack of difference in activities of enzymes involved in protein catabolism (calpains and proteasome) reported recently on a larger group of animals from the same experiment (Le Naou et al., 2012). On the other hand, an increased activity of the calpastatin, an endogenous calpain (calcium-dependent cysteine protease) inhibitor, and a decreased $20 \mathrm{~S}$ proteasome protein degradation systems have been reported in muscle of a $\mathrm{RFI}^{-}$versus a $\mathrm{RFI}^{+}$pig line (Cruzen et al., 2013), suggesting a lower protein degradation rate in $\mathrm{RFI}^{-}$pigs. A reduction in the rate of protein breakdown along with a higher level of calpastatin has been reported in a $\mathrm{RFI}^{-}$line of cattle (McDonagh et al., 2001). We have no particular explanation for the discrepancies between our study and other studies, except the fact that different techniques were used. Le Naou et al. (2012) measured overall 26S proteasome activity (association of 20S subunit with 1 or 219 S regulatory complexes), whereas Cruzen et al. (2013) measured the proteolytic core complex 20S. Altogether, further studies are needed to clarify the effects of RFI selection on protein turnover.

Finally, translation needs abundant sources of energy, particularly ATP, which is essentially produced by oxidative metabolism and phosphorylation in mitochondria. When reducing equivalents produced by fatty acid oxidation and tricarboxylic acid cycle are oxidized, both ATP and ROS are produced, and ROS production may limit ATP production. In the present study, superoxide dismutase and glutathione peroxidase 3 at the mRNA level and peroxiredoxin 6 at the protein level were found to be underexpressed in $\mathrm{RFI}^{-}$pigs, which could reflect a lower ROS production in these pigs. In support, recent studies by Bottje and Carstens (2009) and Grubbs et al. (2013a) also showed that genetic selection for $\mathrm{RFI}^{-}$attenuates $\mathrm{H}_{2} \mathrm{O}_{2}$ production in mitochondria, limiting ROS production. 


\section{Conclusion}

Divergent selection for RFI during 7 generations modified gene and protein expressions in pig muscle, so that $\mathrm{RFI}^{-}$pigs exhibited a lower oxidative metabolism in muscle. This was associated with the downregulation of antioxidative molecules, which could reflect a lower muscular oxidative stress in those pigs. The greater lean meat proportion induced by selection in $\mathrm{RFI}^{-}$pigs might be related to a more efficient energy metabolism in muscle, enabling a shift in energy utilization toward lean growth as suggested by the overexpression of genes involved in protein synthesis. The comparisons made in the present study by considering an additional feed-restricted $\mathrm{RFI}^{+}$group indicated that differences between RFI lines were likely not related to differences in feed intake per se. A recent study suggests that the adenosine monophosphate-activated protein kinase pathway could be involved in the underlying mechanisms linking the numerous changes induced by divergent selection on RFI in skeletal muscle (Faure et al., 2013) but further studies are needed to establish these relationships.

\section{LITERATURE CITED}

Barea, R., S. Dubois, H. Gilbert, P. Sellier, J. van Milgen, and J. Noblet. 2010. Energy utilization in pigs selected for high and low residual feed intake. J. Anim. Sci. 88:2062-2072. doi:10.2527/jas.2009-2395

Bo, H., N. Jiang, L. L. Ji, and Y. Zhang. 2013. Mitochondrial redox metabolism in aging: Effect of exercise interventions. J. Sport Health Sci. 2:67-74. doi:10.1016/j.jshs.2013.03.006

Bottje, W. G., and G. E. Carstens. 2009. Association of mitochondrial function and feed efficiency in poultry and livestock species. J. Anim. Sci. 87(E. Suppl.):E48-E63.

Casel, P., F. Moreews, S. Lagarrigue, and C. Klopp. 2009. SigReannot: An oligo-set re-annotation pipeline based on similarities with the Ensembl transcripts and Unigene clusters. BMC Proc. 3(Suppl. 4):S3.

Colinet, H., D. Renault, B. Charoy-Guevel, and E. Com. 2012. Metabolic and proteomic profiling of diapause in the aphid parasitoid praon volucre. PLoS ONE 7:e32606. doi:10.1371/ journal.pone.0032606

Cruzen, S. M., A. J. Harris, K. Hollinger, R. M. Punt, J. K. Grubbs, J. T. Selsby, J. C. M. Dekkers, N. K. Gabler, S. M. Lonergan, and E. Huff-Lonergan. 2013. Evidence of decreased muscle protein turnover in gilts selected for low residual feed intake. J. Anim. Sci. 91:4007-4016. doi:10.2527/jas.2013-6413

De Haer, L. C. M., P. Luiting, and H. L. M. Aarts. 1993. Relations among individual (residual) feed intake, growth-performance and feed-intake pattern of growing pigs in-group housing. Livest. Prod. Sci. 36:233-253. doi:10.1016/03016226(93)90056-N

Dennis, G., B. T. Sherman, D. A. Hosack, J. Yang, W. Gao, H. C. Lane, and R. A. Lempicki. 2003. DAVID: Database for annotation, visualization, and integrated discovery. Genome Biol. 4:R60. doi:10.1186/gb-2003-4-9-r60

Fatigati, V., and R. A. Murphy. 1984. Actin and tropomyosin variants in smooth muscles - Dependence on tissue type. J. Biol. Chem. 259:4383-4388.
Faure, J., L. Lefaucheur, N. Bonhomme, P. Ecolan, K. Meteau, S. M. Coustard, M. Kouba, H. Gilbert, and B. Lebret. 2013. Consequences of divergent selection for residual feed intake in pigs on muscle energy metabolism and meat quality. Meat Sci. 93:37-45. doi:10.1016/j.meatsci.2012.07.006

Gilbert, H., J. P. Bidanel, J. Gruand, J. C. Caritez, Y. Billon, P. Guillouet, H. Lagant, J. Noblet, and P. Sellier. 2007. Genetic parameters for residual feed intake in growing pigs, with emphasis on genetic relationships with carcass and meat quality traits. J. Anim. Sci. 85:3182-3188. doi:10.2527/jas.2006-590

Grubbs, J. K., A. N. Fritchen, E. Huff-Lonergan, J. C. M. Dekkers, N. K. Gabler, and S. M. Lonergan. 2013a. Divergent genetic selection for residual feed intake impacts mitochondria reactive oxygen species production in pigs. J. Anim. Sci. 91:21332140. doi:10.2527/jas.2012-5894

Grubbs, J. K., A. N. Fritchen, E. Huff-Lonergan, N. K. Gabler, and S. M. Lonergan. 2013b. Selection for residual feed intake alters the mitochondria protein profile in pigs. J. Proteomics 80:334-345. doi:10.1016/j.jprot.2013.01.017

Hang, J., L. Kong, J. W. Gu, and T. H. Adair. 1995. VEGF gene expression is upregulated in electrically stimulated rat skeletal muscle. Am. J. Physiol. 269:H1827-H1831.

Huang, D. W., B. T. Sherman, R. Stephens, M. W. Baseler, H. C. Lane, and R. A. Lempicki. 2008. DAVID gene ID conversion tool. Bioinformation 2:428-430. doi:10.6026/97320630002428

Hwang, I. H., B. Y. Park, J. H. Kim, S. H. Cho, and J. M. Lee. 2005. Assessment of postmortem proteolysis by gel-based proteome analysis and its relationship to meat quality traits in pig longissimus. Meat Sci. 69:79-91. doi:10.1016/j.meatsci.2004.06.019

Le Naou, T., N. Le Floc'h, I. Louveau, H. Gilbert, and F. Gondret. 2012. Metabolic changes and tissue responses to selection on residual feed intake in growing pigs. J. Anim. Sci. 90:47714780. doi: $10.2527 /$ jas.2012-5226

Lefaucheur, L., B. Lebret, P. Ecolan, I. Louveau, M. Damon, A. Prunier, Y. Billon, P. Sellier, and H. Gilbert. 2011. Muscle characteristics and meat quality traits are affected by divergent selection on residual feed intake in pigs. J. Anim. Sci. 89:9961010. doi:10.2527/jas.2010-3493

Lkhagvadorj, S., L. Qu, W. Cai, O. P. Couture, C. R. Barb, G. J. Hausman, D. Nettleton, L. L. Anderson, J. C. M. Dekkers, and C. K. Tuggle. 2010. Gene expression profiling of the short-term adaptive response to acute caloric restriction in liver and adipose tissues of pigs differing in feed efficiency. Am. J. Physiol. Regul. Integr. Comp. Physiol. 298:R494-R507. doi:10.1152/ ajpregu.00632.2009

McDonagh, M. B., R. M. Herd, E. C. Richardson, V. H. Oddy, J. A. Archer, and P. F. Arthur. 2001. Meat quality and the calpain system of feedlot steers following a single generation of divergent selection for residual feed intake. Aust. J. Exp. Agric. 41:1013-1021. doi:10.1071/EA00024

Meunier-Salaün, M. C., C. Guérin, Y. Billon, P. Sellier, J. Noblet, and H. Gilbert. 2014. Divergent selection for residual feed intake in group-housed growing pigs: Characteristics of physical and behavioural activity according to line and sex. Animal 8:1898-1906. doi:10.1017/S1751731114001839

Neufeld, G., T. Cohen, S. Gengrinovitch, and Z. Poltorak. 1999. Vascular endothelial growth factor (VEGF) and its receptors. FASEB J. 13:9-22.

Pette, D., and R. S. Staron. 1997. Mammalian skeletal muscle fiber type transitions. Int. Rev. Cytol. 170:143-223. doi:10.1016/ S0074-7696(08)61622-8

Pfaffl, M. W. 2001. A new mathematical model for relative quantification in real-time RT-PCR. Nucleic Acids Res. 29:e45. doi:10.1093/nar/29.9.e45 
Qin, W. N., Z. Khuchua, J. Boero, R. M. Payne, and A. W. Strauss. 1999. Oxidative myocytes of heart and skeletal muscle express abundant sarcomeric mitochondrial creatine kinase. Histochem. J. 31:357-365. doi:10.1023/A:1003748108062

R Development Core Team. 2008. R: A language and environment for statistical computing. R Foundation for Statistical Computing, Vienna, Austria. http://www.R-project.org. (Accessed 8 December 2011.)

Radak, Z., H. Y. Chung, and S. Goto. 2005. Exercise and hormesis: Oxidative stress-related adaptation for successful aging. Biogerontology 6:71-75. doi:10.1007/s10522-004-7386-7

Richardson, E. C., and R. M. Herd. 2004. Biological basis for variation in residual feed intake in beef cattle. 2. Synthesis of results following divergent selection. Aust. J. Exp. Agric. 44:431-440. doi:10.1071/EA02221

Richardson, R. S., H. Wagner, S. R. D. Mudaliar, E. Saucedo, R. Henry, and P. D. Wagner. 2000. Exercise adaptation attenuates VEGF gene expression in human skeletal muscle. Am. J. Physiol. Heart Circ. Physiol. 279:H772-H778.
Schlicker, A., F. S. Domingues, J. Rahnenführer, and T. Lengauer. 2006. A new measure for functional similarity of gene products based on Gene Ontology. BMC Bioinformatics 7:302.

Supek, F., M. Bosnjak, N. Skunca, and T. Smuc. 2011. REVIGO Summarizes and visualizes long lists of gene ontology terms. PLoS ONE 6:e21800. doi:10.1371/journal.pone.0021800

Vandesompele, J, K. De Preter, F. Pattyn, B. Poppe, N. Van Roy, A. De Paepe, and F. Speleman. 2002. Accurate normalization of real-time quantitative RT-PCR data by geometric averaging of multiple internal control genes. Genome Biol. 3:RESEARCH0034.

Vincent, A., I. Louveau, F. Gondret, B. Lebret, and M. Damon. 2012. Mitochondrial function, fatty acid metabolism, and immune system are relevant features of pig adipose tissue development. Physiol. Genomics 44:1116-1124. doi:10.1152/physiolgenomics.00098.2012 